\title{
Permian glossopterid scale leaves from the La Golondrina Formation (Santa Cruz, Argentina): the neglected members of Glossopteris floras
}

\author{
Bárbara CARIGLINO \\ Museo Argentino de Ciencias Naturales - CONICET. Av. Angel Gallardo 470, C1405DJR, Buenos Aires, \\ Argentina. barichi10@gmail.com
}

\begin{abstract}
Glossopterid scale leaves from the La Golondrina Formation are described and analyzed. Three different types are recognized based on their morphological differences and venation patterns. Type A scale leaves are triangular in shape, have central veins running straight to the apex, and lateral veins dichotomizing once or twice before reaching the margins. Type B scales have wide-ranging shapes, and a number of separate, central veins running straight upwards, dividing and anastomosing several times, while lateral veins arch towards the margin, forming meshes that become shorter and numerous closer to the margins. Last, Type $\mathrm{C}$ scale leaves are triangular to rhombic, sometimes subcircular, convex scales, furrowed by straight, sub-parallel veins that arise from the base and reach the distal margin, occasionally dichotomizing closer to the margins. The lower and middle parts of these scales are covered by rounded, small punctuations. The artificial classification here proposed is solely for the purpose of identification of these elements, and do not necessarily imply relationships. The different types of scales could have acted as protection of buds and/or fertile parts or as disperser of the latter once they were ripe.
\end{abstract}

Key words: Argentina, Glossopteris, La Golondrina Formation, Permian, scale leaves.

Resumen: Escamas foliares de glossopterídeas pérmicas de la Formación La Golondrina (Santa Cruz, Argentina): los componentes poco conocidos de la Flora de Glossopteris. Se describen y analizan escamas foliares de glossopterídeas provenientes de la Formación La Golondrina. Se reconocen tres tipos diferentes sobre la base de sus diferencias morfológicas y patrones de venación. Las escamas foliares Tipo A presentan forma triangular; las venas centrales corren desde la base hasta el ápice, con las venas laterales dicotomizándose una o dos veces antes de llegar a los bordes. Las escamas foliares tipo B tienen variadas formas; las venas centrales marchan en línea recta hacia el ápice, dividiéndose y anastomosándose varias veces, mientras que las venas laterales se arquean hacia los márgenes, formando polígonos que se vuelven más cortos y numerosos al llegar a los bordes. Por último, las escamas foliares Tipo $\mathrm{C}$ presentan formas triangulares, romboidales o subcirculares, son escamas convexas, surcadas por venas rectas sub-paralelas que surgen desde la base y alcanzan el margen distal, ocasionalmente dicotomizandose cerca de los márgenes. La parte media-inferior de estas escamas está cubierta por un puntuado de origen incierto. La clasificación artificial aquí propuesta es únicamente con el propósito de identificación de estos elementos, y no implica necesariamente relaciones filogenéticas. Los diferentes tipos de escamas podrían haber actuado como protección de los brotes y/o partes fértiles o como dispersor de éstas, una vez que estaban maduras.

Palabras clave: Argentina, Glossopteris, Formación La Golondrina, Pérmico, escamas foliares.

\section{INTRODUCTION}

The Permian fossil flora from the La Golondrina Formation (Archangelsky, 1967) from the Santa Cruz Province, Argentina, has been extensively studied since it was discovered in the early 1950s. Important contributions by different authors described a flora with abundant glossopterids, ferns, sphenophytes, and to a lesser degree, lycophytes and cordaites (Archangelsky, 1959, 1960; Archangelsky
\& De la Sota, 1960; Arrondo, 1972; Herbst, 1978; Archangelsky \& Cúneo, 1984, 2002; Archangelsky et al., 1996a, 2004; Cariglino, 2011). Glossopterids are the dominant group in this flora, and are represented by both sterile (i.e., Glossopteris and Gangamopteris leaves, Vertebraria sp.) and fertile elements (i.e., Dictyopteridium sporiferum, Plumsteadia pedicellata, etc.) (Archangelsky, 1957, 1959, 1992; Archangelsky \& Bonetti, 1963; Cariglino et al., 2009). 

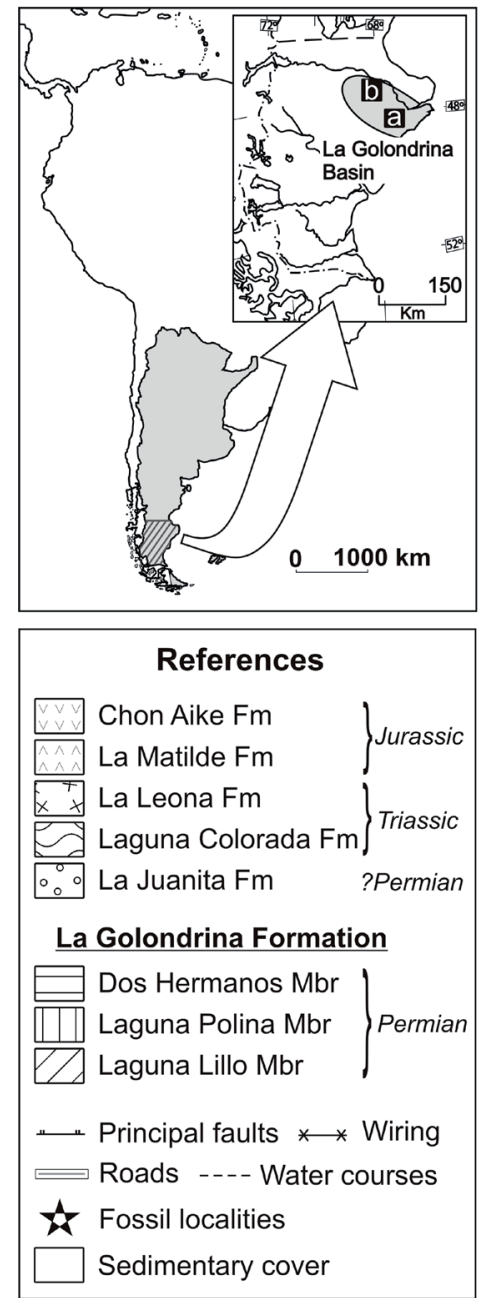

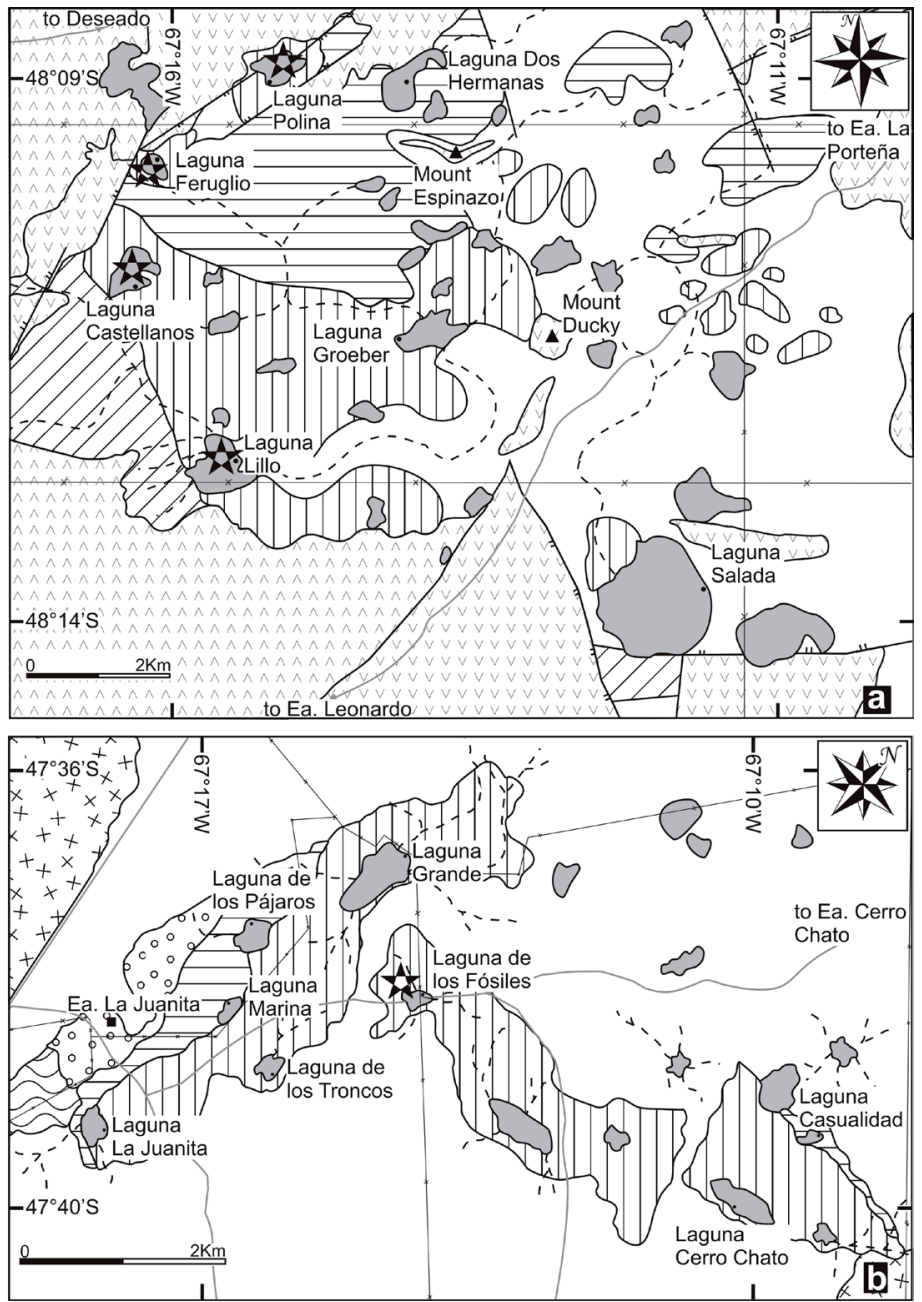

Fig. 1. Geological maps of the Bajo de La Leona (a) and Estancia La Juanita (b) areas showing the Permian outcrops of the La Golondrina Formation fossil localities (modified from Panza, 1994 and Jalfin, 1987).

Glossopterid scale leaves are found all over Gondwana throughout the Permian, but are more common in Upper Permian strata (Anderson \& Anderson, 1985; McLoughlin et al., 2005). Despite of being a recurrent element in Glossopteris floras, their mention is usually belittled, probably because of the lack of knowledge that still surrounds these elements. Previous works by Archangelsky (1957) and Arrondo (1972) reported their presence at the La Golondrina Formation and provided brief descriptions of some of these scales. Glossopterid scales were first mentioned by Feistmantel (1881), who assigned detached scale leaves from different localities of India to the general name of Squamae. Zeiller (1902) identified a similar anastomosing venation as in Glossopteris for isolated scales, allowing him to infer relations with the glossopterids. However, even if they were frequently in association with Glossopteris, no evidence of direct connection was known, until Surange \& Chandra (1974, 1975) described glossopterid reproductive organs borne on scale leaves.

The aim of this paper is to present the glossopterid scales found at the La Golondrina Formation. This work includes the revision and description of the material previously collected by Archangelsky (1957) and Arrondo (1972), the one from other collections unstudied until now, and new material recently collected during fieldtrips to the areas of Bajo de La Leona and Estancia La Juanita (Fig. 1, Table 1). Based on morphological differences, mostly on their venation patterns, three different types of scales 
Table 1. Collection material used in this study.

\begin{tabular}{lrlcc}
\hline \multicolumn{1}{c}{ Collection } & Year & \multicolumn{1}{c}{ Housed $\boldsymbol{a t}$} & Acronym & Studied \\
\hline Criado Roque & 1953 & Fundación Miguel Lillo, Tucumán & LIL Pb & Yes \\
Archangelsky & $1956 / 7$ & Fundación Miguel Lillo, Tucumán & LIL Pb & Yes \\
Arrondo & 1969 & Museo de La Plata, La Plata & LP Pb & Yes \\
Azcuy, Césari, & 1982 & $\begin{array}{l}\text { Facultad de Cs. Exactas y Naturales, UBA, Buenos } \\
\text { Longobucco, Ottone }\end{array}$ & BAFC Pb & No \\
Archangelsky \& Cúneo & $1984 / 8$ & Museo Argentino de Cs. Naturales, Buenos Aires & BA Pb & No \\
Cariglino $e t$ al. & $2008 / 10$ & $\begin{array}{l}\text { Museo Regional Provincial "Padre Jesús Molina", } \\
\text { Santa Cruz }\end{array}$ & MPM Pb & No \\
\hline
\end{tabular}

are identified, and their potential function is discussed.

\section{MATERIALS AND METHODS}

The specimens from this study come from the Paleobotany Collections at Fundación Miguel Lillo (LIL Pb; Criado Roque 1953 and Archangelsky 1956/7 Collections) in Tucumán, Museo de La Plata (LP Pb; Arrondo 1969 Collection) in La Plata, Facultad de Ciencias Exactas y Naturales (Universidad de Buenos Aires, BAFC Pb; Azcuy, Césari, Longobucco and Ottone 1982 Collection) and Museo Argentino de Ciencias Naturales (BA $\mathrm{Pb}$; Archangelsky and Cúneo 1984/8 Collection) in Buenos Aires.

New specimens were collected on recent field trips to the areas of Bajo de La Leona and Estancia La Juanita, where the La Golondrina Formation outcrops in the Deseado Massif, in the northeastern region of the Santa Cruz Province (Fig. 1). According to Archangelsky et al. (1996a), the formation is divided into three members, from bottom to top: Laguna Lillo, Laguna Polina and Dos Hermanos (Jalfin, 1987, 1990; Jalfin et al., 1990; Archangelsky et al., 1996a). The megafloral remains in this formation were referred to the Dizeugotheca Superbiozone (Archangelsky \& Cúneo, 1984; Archangelsky et al., 1996b), and consequently a late-Early to Late Permian age was inferred (Archangelsky, 1992, 2006; Archangelsky et al., 1996a, 1996b, 2004; Andreis, 2002). The newly recovered material is housed at the Museo Provincial Regional "Padre Jesús Molina" (MPM Pb) at Río Gallegos. All the scale leaves in this study were recovered from siltstones and fine grained sandstones levels from the middle member of the unit at the localities of Laguna Polina, Laguna Castellanos, Laguna Feruglio at the Bajo de La Leona, and Laguna de los Fósiles at Estancia La Juanita (Fig. 1).
Specimens were photographed using a Canon Powershot S5IS (8.0 megapixel) digital camera. For detailed analysis and illustration, specimens were photographed under strong unilateral, low-angled light with a Nikon DS.Fi1-U2 digital camera attached to a Nikon SMZ800 stereomicroscope. Scaling and adjustment of images was accomplished using Adobe Photoshop CS3 software. Detailed images were taken with a Philips XL30 scanning electron microscope.

\section{DESCRIPTION OF THE SCALE LEAVES}

Three different types of scale leaves were recognized based primarily on shape and venation pattern differences.

\section{Type A scale leaves}

(Figs. 2 a-b, 3)

Specimen number. MPM Pb 2609, LIL Pb 99 Description. MPM Pb 2609 is a triangular scale $23 \mathrm{~mm}$ long (top is missing) and $10.3 \mathrm{~mm}$ at widest point (approximate $\mathrm{L}: \mathrm{W}=2.2$ ). The base is asymmetrical and somewhat rounded, and the scale tapers to the apex. The widest part is at the first third from the base. Veins run straight at the base and curve to one side at the middle of the scale. Veins dichotomize one or two times before reaching the margin. No clear anastomoses are observed. Margin $1.2 \mathrm{~mm}$ thick.

LIL $\mathrm{Pb} 99$ is an almost complete scale 27.7 $\mathrm{mm}$ long and $16.3 \mathrm{~mm}$ at widest point $(\mathrm{L}: \mathrm{W}=$ 1.7). It has a lanceolate shape, apex acute and base truncated. Veins spread from the base, forking and anastomosing few times while arching towards the margins.

Locality, unit and age. Laguna Polina (LIL $\mathrm{Pb}$ 99), Laguna Feruglio (MPM Pb 2609); La Golondrina Formation (Laguna Polina Member); Guadalupian-Lopingian. 
Remarks. Type A scale MPM Pb 2609 described here is similar to the one described by Cridland (1963, p. 189, fig. 7, 36-38) for a Glossopteris flora from Antarctica. It bears resemblance in the shape and size, although the specimen from $\mathrm{La}$ Golondrina is slightly more elongated. The venation pattern is also similar, with dichotomizing veins tending to one side of the scale. Pant (1958, p. 159 , plate 20 , figs. 3 , 4 ; text-fig 15a) described similar scales for Tanganyika (nowadays, territory of Tanzania) with a lanceolate shape, pointed apex, and a rounded (cordate) base. These scales have veins spreading from the base that arched towards the margin, occasionally forking and anastomosing. The asymmetrical shape, the tendency to one side of the scale in the venation and the presence of thick margin may be indicative of a rolled up scale to offer protection, while Pant's scales could be representing the same type of scale, unrolled. These types of scales are not as abundant as the other types, and thus, more information is needed to infer it possible function and affinities.

\section{Type B scale leaves}

(Figs. 2 c-f, 3)

Specimen number. LIL $\mathrm{Pb} 101,1436,1439$, BAFC Pb 15540, BA Pb 13923, 13925, LP Pb 7088

Description. Various different shapes, from triangular to rhomboidal, from lanceolate to oblanceolate, from ovate to obovate, or spathulate. Sizes range from 13.6 to $40 \mathrm{~mm}$ long and 18.75 to $36.2 \mathrm{~mm}$ wide. Length to width ratio is $0.9: 1$. Apex acute to rounded; tip pointed to blunted. Base truncated to broadly attenuate. No midrib present, but a number of separate, central veins run straight upwards, dividing and anastomosing several times, but only in the apical region. Lateral veins arch towards the margin, dividing and anastomosing. Meshes become shorter and numerous closer to the margins.

Locality, unit and age. Laguna Polina (LIL $\mathrm{Pb}$ 101, 1436, 1439, BAFC Pb 15540), Laguna Castellanos (BA Pb 13923, 13925), Ea. La Juanita (LP Pb 7088); La Golondrina Formation (Laguna Polina Member); Guadalupian-Lopingian.

Remarks. Type B scales are common elements in the Gondwanan floras (Thomas, 1958; Chandra \& Surange, 1977; Anderson \& Anderson,
1985). Within the La Golondrina Formation, a few have been previously found and described (Archangelsky, 1957; Arrondo, 1972). The size and shape of these scales is very variable, from ovate to obovate, rhomboidal to triangular, with rounded apex with a pointed tip to an acute, long apex. The base is truncated since scales are detached from the stalk on which the fertile parts are borne they generally does not get preserved (Chandra \& Surange, 1977). The venation pattern is almost the same in all these scales. There is no midrib; a group of central veins run from the base of the scale lamina straight to the apex, and a couple of them not dividing. The lateral veins open out towards the margin, arching, forking and anastomosing in long meshes, except closer to the margin, where meshes are shorter and more numerous. The line sketches on Chandra \& Surange's paper (1977) show complete scale leaves that if the stalk is detached are very similar to the scales here described. All the scales represented by Chandra \& Surange (1977) are assigned to taxa from the Lidgettoniaceae.

\section{Type C scale leaves}

(Figs. 2 g-l, 3)

Specimen number. MPM Pb 4430, 4453, 4454, 4456, 4468, 4472, 4821, LP Pb 7109, 7115, 7121, 7147,7371

Description. Triangular to subrhomboidal, convex scales. Sizes range from 8.3 to $16.24 \mathrm{~mm}$ in length and 7.3 to $14.52 \mathrm{~mm}$ in width, and the length to width relation is ca. 1.1:1. Apex rounded to acute, laterals rounded to angular. Scales are furrowed by straight, sub-parallel veins that arise from the base and reach the distal margin. Few dichotomies are sometimes observed closer to the margin. The lower and middle parts of the scales are covered by rounded, small punctuations.

Locality, unit and age. Estancia La Juanita (all LP Pb specimens; MPM Pb 4453, 4454, 4456, 4468, 4472), Laguna Polina (MPM Pb 4821) and Laguna Castellanos (MPM Pb 4430); La Golondrina Formation (Laguna Polina Member); Guadalupian-Lopingian.

Remarks. Type C scales present strong, subparallel furrows running from base to apex giving these scales a more robust appearance compared to Type A and B scales. In addition, the

Fig. 2. Type A scale leaves, a LIL Pb 99, b MPM Pb 2609. Type B scale leaves, c BAFC Pb 15540, d LIL Pb 1436, arrow points a smaller, Type C scale, e LIL Pb 101, f LIL Pb 1439. Type C scales, g MPM Pb 4454, h MPM Pb 4453, i MPM Pb 4468, j LP Pb 7121, k LP Pb 7371, 1 LP Pb 7371 M.E.B image. All scales 5 mm, except (l) 2 mm. 

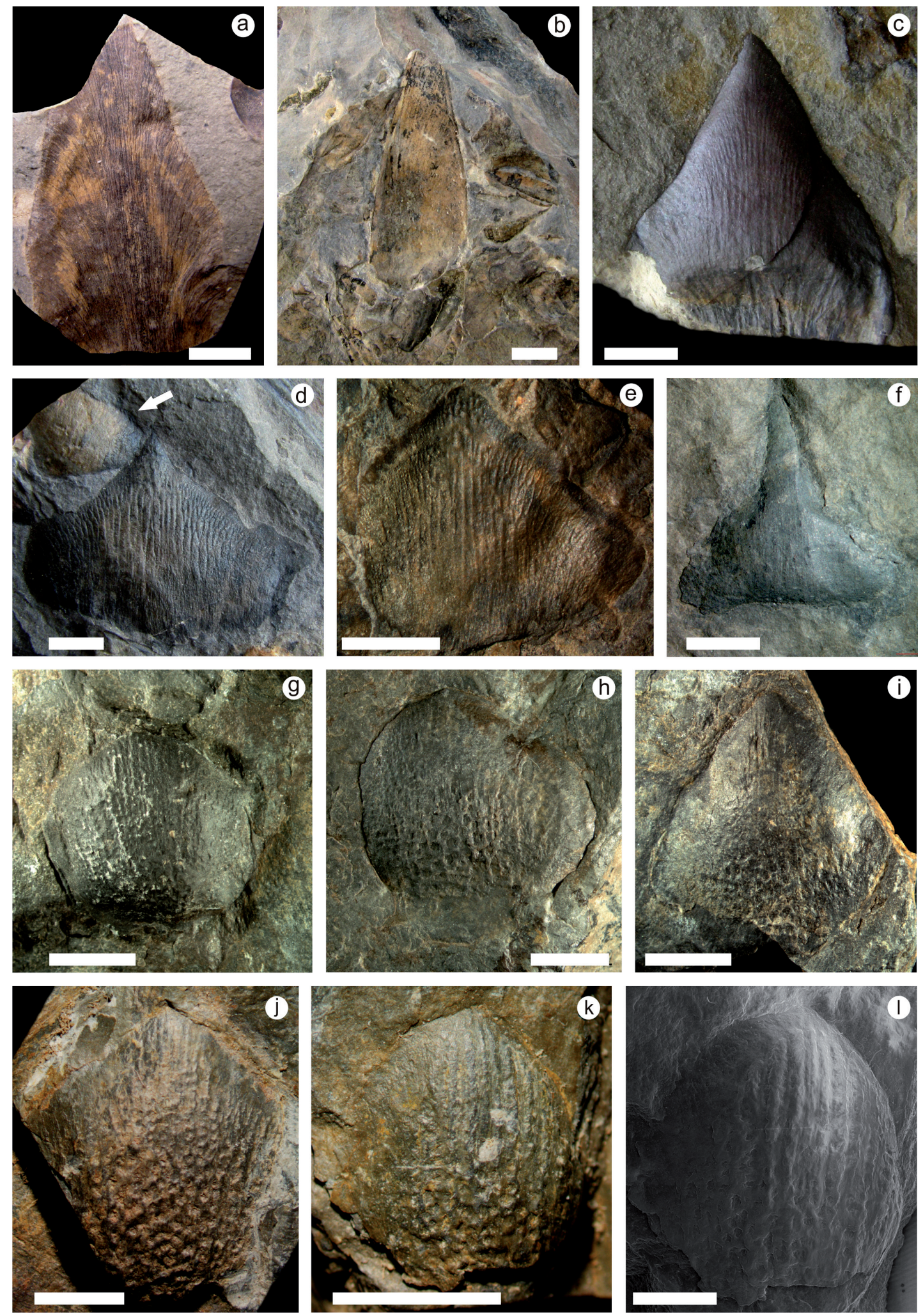


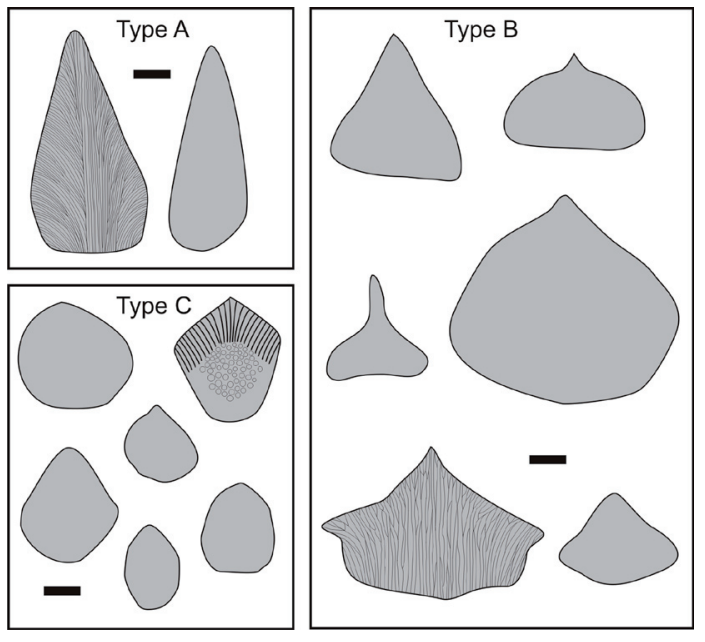

Fig. 3. Comparative schematic outline and venation pattern of Types A, B and C scale leaves. All scales $5 \mathrm{~mm}$.

central part of the scales present circular marks that are absent in the other two types.

\section{DISCUSSION}

Up to date, several attempts to classify scale leaves have been made, various genera proposed, and diverse interpretations about their function speculated, reaching few consensuses among scholars (e.g., Pant, 1958; Chandra \& Surange, 1977; Banerjee, 1984; Anderson \& Anderson, 1985).

Pant (1958) described scale leaves from the Upper Coal Measures (Middle Permian) of Tanganyika, but since he could not prove the presence of sporangia or seeds, he disregarded them as reproductive organs. Later, Chandra \& Surange (1977) described detached scales based on shape, size, and venation pattern. They advocated that even in detached conditions, scales could be "easily assigned to their respective genera established for the reproductive organs of Glossopteris" (Chandra \& Surange, 1977, p. 195). However, if the capitula or microsporangia are separated from the scale, their assignation to a certain genus could be misleading, since most fructifications are assigned based on the presence of different female or male structures, not the scale in which they are borne. Banerjee (1984) considered that scales presented significant characteristic features deserving generic status, and classified them under four genera (Gondwanolepis, Ghoshialepis, Mahudaea, Bankolaea) basing on their occurrence (e.g., singly or in group) and general physiognomy. On the other hand, Anderson
\& Anderson (1985) classified four different scaleleaf genera (A to D) using similar criteria as in this study (Table 2).

White (1978) suggested that these deciduous scales ('squamae') together with a laminal segment composed a "scale-frond", and a group of "scale-fronds" formed a cone. Squamella is the form-genus White (1978) used to name scalefronds aggregated into cones. Cones were born at the ends of branches, and could be either sterile or fertile (White, 1978; McLoughlin et al., 2005; Adendorff, 2005). Scales would have acted as protection for the sporangia in young cones. When cones were ripe, the deciduous scales would fall and the laminal segments would elongate to allow the sporangia to hang out and disperse the spores (White, 1978, p. 477). Even if there is not enough evidence from the La Golondrina Formation that supports White's hypothesis on the organization of a cone and its development, the presence of this kind of scales may account for the existence of cone-like structures.

Here, scales are divided in three different categories principally based on their venation and basic morphologic features. This artificial separation, however, does not rule out the possibility that they all could belong to the same group (i.e., Lidgettoniaceae).

Detached scales are considered part of a glossopterid reproductive structure. Nevertheless, their function cannot be definitely specified. Most probably, scales would provide of protection to the reproductive parts it bore (e.g., microsporangia or capitula) in the early stages of reproduction. They could also act as a mean of transport (e.g. some sort of wing) away from the mother plant, once it was mature. It has also been suggested that scales protected the buds during growth of the Glossopteris plant (McLoughlin et al., 2005; Adendorff, 2005).

Up to date, the only reached consensus on glossopterid scale leaves is that they were either fertile or sterile, probably with different functions (protection of fertile structures vs. dispersal of fertile structures), and they belonged to the Glossopteris plant. It is still debated whether these structures were always grouped in cones, or displayed individually.

The apparent curl in Type A scales seem to have acted as protective, either of fertile structures or buds during the growth of the plant. Glossopteris was a deciduous plant, spending part of the year leaf-less. Maybe the growth of new leaves when climatic conditions allowed was preceded by scaly buds, as in some modern plants. 
Type B scale leaves, on the other hand, have been found to be part of fertile structures, bearing both micro and megasporangia in the Lidgettoniaceae (as in Eretmonia sp. and Lidgettonia sp.). Last, Type $\mathrm{C}$ scale leaves have been found isolated as well as aggregated into cones (White, 1978). A cone could have acted protecting the fertile structures, and once ripe, it would open and maybe act as effective seed dispersal. The origin of the circular marks on this type of scales is unknown. Some hypotheses could be that such marks are the base of trichomes or that they were produced by the contact of the scales (acting as a protective cover) of an ovule-bearing structure, being those marks the imprint of the ovules or seeds. On the other hand, it has been suggested that the texturing in Type $\mathrm{C}$ scales would be an artifact of preservation (Dr. Prevec, pers. comm.). In any case, until its origin is explained, it should be considered as a diagnostic feature merely for the purpose of this classification.

\section{CONCLUSIONS}

This study identifies three different types of Glossopteris scale leaves based on their venation pattern and overall physiognomy. This artificial assignation of types, however, is proposed for the sake of easiness in their identification, and by any means is intended to explain relationships or their potential functions. The different types could be representing different groups, stages on the development, functionality, or even preservational artifacts.

This artificial classification will surely change with further findings, especially of scales aggregated into cones or bearing their reproductive structures in connection with Glossopteris leaves, which will help to elucidate their true relations, as well as their real function in the Glossopteris plant.

\section{ACKNOWLEDGMENTS}

To P. R. Gutiérrez, G. Correa and E. P. Coturel for assistance in the field. To S. Archangelsky for sharing bibliography. To L. Balarino, S. Césari and an anonymous reviewer for constructive critics that improved the manuscript. To M. Iberlucea and F. Tricárico for technical assistance. To M. Fjell and B. San Juan for access to the Estancia La Golondrina and Estancia Leonardo, respectively. To H. Carrizo and E. Fernández (Fundación Miguel Lillo), L. Lezama (Museo Argentino de Ciencias Naturales), M. Tánuz

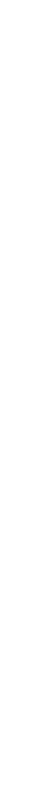

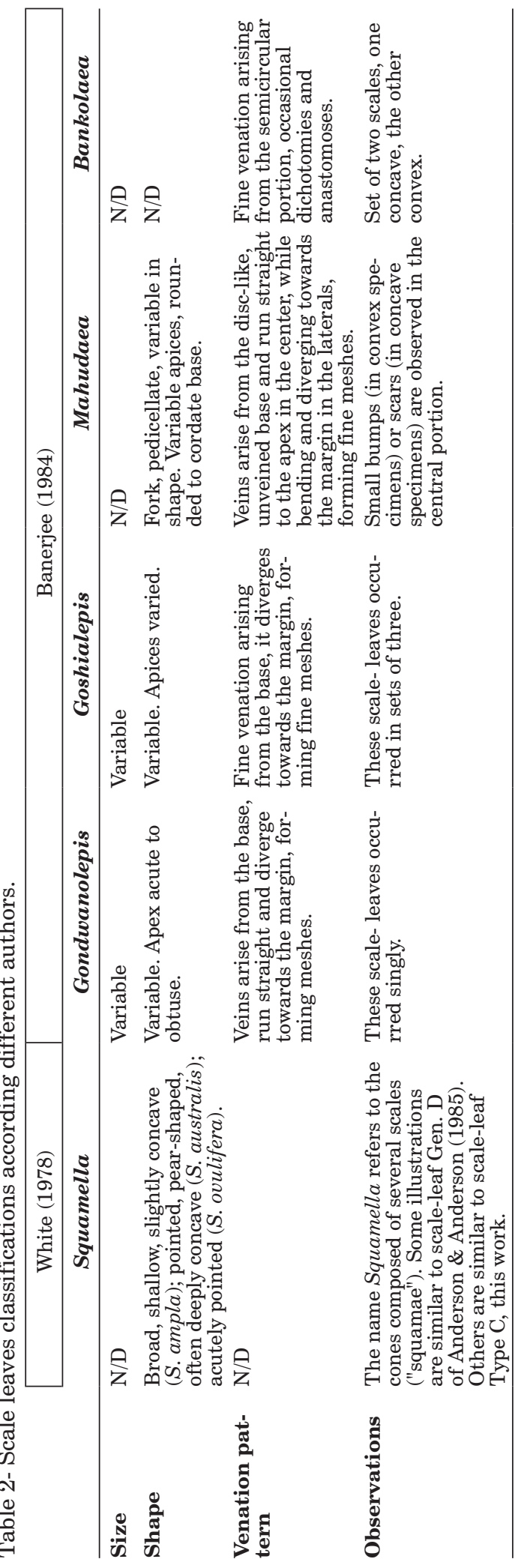




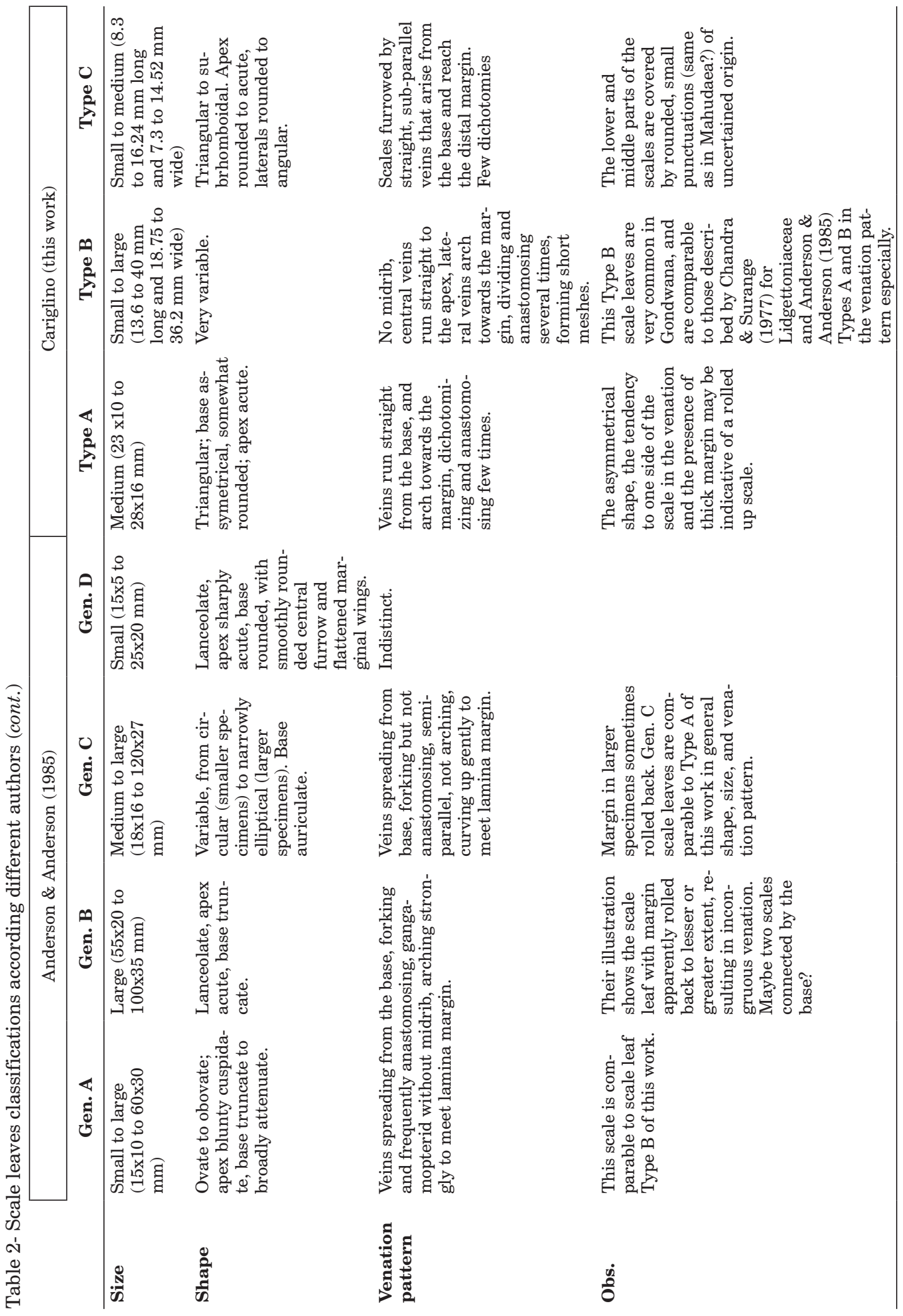


(Facultad de Ciencias Exactas y Naturales, UBA) and A. Zúñiga (Museo de La Plata), for facilitating the access to the collections. Research was funded by PICT 32693/05 of the Agencia de Promoción Científica y Tecnológica of Argentina, and CONICET-PIP 2007-5723 and 2009-0705.

\section{BIBLIOGRAPHY}

Adendorff, R. 2005. A revision of the ovuliferous fructifications of glossopterids from the Permian of South Africa. Unpublished Ph.D. Thesis, University of the Witwatersrand, Johannesburg, 421 pp.

Anderson, J.M. \& H.M. Anderson. 1985. Palaeoflora of southern Africa. Prodromus of South African megafloras: Devonian to Lower Cretaceous. Rotterdam: A.A. Balkema, $423 \mathrm{pp}$.

Andreis, R.R. 2002. Cuenca La Golondrina (depósitos del rift pérmico y evento magmáticos triásicos). En: M.J. Halle (Ed.), Geología y Recursos Naturales de Santa Cruz, Relatorio del $15^{\circ}$ Congreso Geológico Argentino (El Calafate), pp. 71-82.

Archangelsky, S. 1957. Las glossopterídeas del Bajo de La Leona (Santa Cruz). Revista de la Asociación Geológica Argentina 12: 135-164.

Archangelsky, S. 1959. Estudio geológico y paleontológico del Bajo de la Leona (Santa Cruz). Acta Geológica Lilloana 2 [1958]: 5-133.

Archangelsky, S. 1960. Lycopsida y Sphenopsida del Paleozoico superior de Chubut y Santa Cruz, Patagonia. Acta Geológica Lilloana 3: 21-36.

Archangelsky, S. 1967. Estudio de la Formación Baqueró. Cretácico Inferior de Santa Cruz, Argentina. Revista del Museo de La Plata (nueva serie), Paleontología 32 (5): 63-171.

Archangelsky, S. 1992. Dictyopteridium Feistmantel (fructificaci6n pérmica de glossopteridales): primer registro argentino. VII ${ }^{o}$ Simposio Argentino de Paleobotánica y Palinologia. Publicación Especial de la Asociación Paleontológica Argentina 2: 19 22.

Archangelsky, S. 2006. Dizeugotheca waltonii (Biozona de Intervalo de). En: P.R. Gutiérrez, E.G. Ottone \& S.M. Japas, (Eds.), Léxico Estratigráfico de la Argentina. Volumen VII. Pérmico. Asociación Geológica Argentina, Serie B (Didáctica y Complementaria) 28: 108-109.

Archangelsky, S. \& M. Bonetti. 1963. Fructificaciones de glossopterídeas del Pérmico del Bajo de la Leona, Provincia de Santa Cruz. Ameghiniana 3: 29-34.

Archangelsky, S. \& N.R. Cúneo. 1984. Zonación del Pérmico continental argentino sobre la base de sus plantas fósiles. Memorias del III ${ }^{o}$ Congreso Latinoamericano de Paleontología, pp. 143-153. México.

Archangelsky, S. \& N.R. Cúneo. 2002. Floras del Paleozoico superior. Cuenca La Golondrina. En: M.J. Haller, (Ed.), Geología y Recursos Naturales de Santa Cruz, $\mathrm{XV}^{\circ}$ Congreso Geológico Argentino (El Calafate), Relatorio, pp. 401-405. Buenos Aires.
Archangelsky, S. \& E. De la Sota. 1960. Contribución al conocimiento de las fílices pérmicas de la Patagonia extraandina. Acta Geológica Lilloana 3: 85-126.

Archangelsky, S., G.A. Jalfin \& N.R. Cúneo. 1996a. Cuenca La Golondrina. En: S. Archangelsky (Ed.), El Sistema Pérmico en la República Argentina y en la República Oriental del Uruguay, Academia Nacional de Ciencias, pp. 93-108. Córdoba.

Archangelsky, S., C.L. Azcuy, S.N. Césari, C.R. González, M.A. Hünicken, A. Mazzoni, \& N. Sabattini. 1996b. Correlación y edad de las biozonas. En: S. Archangelsky (Ed.), El Sistema Pérmico en la República Argentina y en la República Oriental del Uruguay, Academia Nacional de Ciencias, pp. 203-226. Córdoba.

Archangelsky, S. S.N. Césari \& N.R. Cúneo. 2004. On some similar Patagonian and Indian Permian Ferns. En: P.C. Srivastava (Ed.), Vistas in Palaeobotany and Plant Morphology: Evolutionary and Environmental Perspectives, Prof. D.D. Pant Memorial Volumen, pp. 71-81. U.P. Offset, Lucknow, India.

Arrondo, O.G. 1972. Estudio geológico y paleontológico de la zona de Estancia La Juanita y alrededores, provincia de santa Cruz, Argentina. Revista del Museo de La Plata (nueva serie), Paleontología 43: $1-194$.

Banerjee, M. 1984. Fertile organs of the Glossopteris flora and their possible relationship in the line of evolution. En: A.K. Sharma (Ed.), Proceedings of a symposium on evolutionary botany and biostratigraphy. A.K. Ghosh Commemoration Volume. New Delhi: Today and Tomorrows Printers and Publishers, pp. 29-59.

Cariglino, B. 2011. El Pérmico de la Cuenca La Golondrina: Paleobotánica, bioestratigrafía y consideraciones paleoecológicas. Unpublished $\mathrm{PhD}$ Thesis, Universidad Nacional de La Plata, Buenos Aires, Argentina, 285 pp.

Cariglino, B., P.R. Gutiérrez \& M. Manassero. 2009. Plumsteadia pedicellata sp. nov.: A new glossopterid fructification from the La Golondrina Formation (Guadalupian-Lopingian), Santa Cruz Province, Argentina. Review of Palaeobotany and Palynology 156: 329-336.

Chandra, S. \& K.R. Surange. 1977. Fertile bracts and scales of Glossopteris fructifications from the Lower Gondwana of India. Palaeobotanist 24: 195-201.

Cridland, A.A. 1963. A Glossopteris flora from the Ohio Range, Antarctica. American Journal of Botany 50: 186-195.

Feistmantel, O. 1881. The fossil flora of the Gondwana System. The flora of the Talchir - Karharbari beds. Memoirs of the Geological Survey of India. Paleontologia Indica (12) 3 (supplement): 49-64.

Herbst, R. 1978. Asterotheca golondrinensis n.sp. from the Lower Permian Golondrina Series of the Bajo de la Leona, Santa Cruz, Argentina. Palaeobotanist 25: $126-130$.

Jalfin, G.A. 1987. Estratigrafia y paleogeografia de las Formaciones La Golondrina y La Juanita, Pérmico de la provincia de Santa Cruz y su relación con rocas 
de edad similar en las Islas Malvinas. Unpublished Ph.D. Thesis. Universidad Nacional de Tucumán. San Miguel de Tucumán, Argentina, 219 pp.

Jalfin, G.A. 1990. Grupo Tres Cerros. Denominación formal para las sedimentitas neopaleozoicas que conforman el relleno de la Cuenca La Golondrina, provincia de Santa Cruz, Argentina. En: Annual Meeting Working Group, Project 211-IGCP, Abstr. pp. 36-39.

Jalfin, G., R. Cúneo \& S. Archangelsky. 1990. Paleoambientes, paleobotánica y bioestratigrafía de la Formación La Golondrina en la localidad Dos Hermanos, Pérmico superior, Santa Cruz, Argentina. En: Annual Meeting Working Group, Project 211-IGCP, Abstr. pp. 18-20.

McLoughlin, S., K. Larsson \& L. Lindström, S. 2005. Permian plant macrofossils from Fossilryggen, Vestfjella, Dronning Maud Land. Antactic Science 17: 73-86.

Pant, D.D. 1958. The structure of some leaves and fructifications of the Glossopteris flora of Tanganyika. Bulletin of the British Museum (Natural History)
Geology 3(4): 127-183.

Panza, J.L. 1994. Hoja Geológica 4966-I/II Bahía Laura, escala 1:250000 (Santa Cruz). Dirección Nacional del Servicio Geológico, Boletín 214.

Surange, K.R. \& S. Chandra. 1974. Some male fructifications of Glossopteridales. Palaeobotanist 21: 255-266.

Surange, K.R. \& S. Chandra. 1975. Morphology of the gymnospermous fructifications of the Glossopteris flora and their relationships. Palaeontographica 149B: 153-180.

Thomas, H.H. 1958. Lidgettonia, a new type of fertile Glossopteris. Bulletin of the British Museum (Natural History) 3: 179-189.

White, M.E. 1978. Reproductive structures of the Glossopteridales in the plant fossil collection of the Australian Museum. Records of the Australian Museum 31: 473-504.

Zeiller, R. 1902. Observations sur quelques plantes fossils des Lower Gondwanas. Memoirs of Geological Survey of India. Palaeontologica indica n.s. 2.

Recibido: 18-X-2012

Aceptado: 11-VI-2013 